\title{
SWOT Analysis on Development for Sports Culture Creative Industry in Liaoning Province
}

\author{
Ying Zhang \\ College of Education And Sports, Bohai University, Jinzhou, 121013, China \\ 47086132@qq.com
}

Keywords: Liaoning province; sports culture creative industry; development

\begin{abstract}
Sports cultural creative industry belongs to the category of cultural and creative industries, but also an important part of sports industry in China. Along with the acceleration of China's sports industry and national "Twelfth Five Year" plan for the cultural and creative industries to support and guide, the development of sports culture and creative industry in China is also showing a good trend. This research uses the theory of culture, economics and regional development, introduces the connotation of sports culture and creative industry, expounds the important significance of developing sports culture and creative industry in Liaoning Province, and analyzes the advantages, disadvantages, opportunities and threats (SWOT) of sports cultural creative industry in Liaoning province.
\end{abstract}

\section{Introduction}

Since entering twenty-first Century, with the development of economy and society, the sports industry in China has developed rapidly, and has become a promising sunrise industry. As an important part of sports industry, sports cultural creative industry is a new industry which has been rising in recent years. It has become a new growth point of sports industry. It has a very good market prospect and strong development potential. It has important strategic significance for optimizing industrial structure and realizing economic growth mode. The national "five eleven" period of cultural development of the cultural and creative industries to the national strategic level, the development of sports and cultural and creative industries as an important target [1]. On November 20, 2011, Liaoning Provincial Government in the CPC Liaoning Provincial Committee on the implementation of the party's seventh session of the Sixth Plenum of the 16th CPC Central Committee, "decided to" speed up the implementation of the views of the construction of cultural province "also proposed play location advantages of Liaoning Province, optimize the industrial structure and layout, to build a group of mobile new media, animation and game, culture, tourism and other well-known brand cultivation, construction with independent intellectual property rights, technology leading cultural and creative industrial district, the further development of the growth of cultural industries policy [2].

At present, sports cultural and creative industry is not only in the developed countries, in Beijing, Shanghai, Shenzhen, Changsha, Nanjing and other big cities have been greatly developed, and its economic benefits continue to show. The development of sports culture and creative industry has become an important choice to enhance the competitiveness of the country under the background of knowledge economy, and also become an important way to strengthen the city's comprehensive strength. At present, Liaoning is in the key period of the revitalization of old industrial base, the development of sports and cultural creative industry is the right time. However, the creative industry of sports culture in Liaoning province is still in the initial stage of development, many problems and factors restrict and affect the development of sports culture and creative industry, which affect the optimization of sports resources and improve the comprehensive strength of our country. Especially in the development of sports culture and creative industry, there are also problems such as theoretical level, development scale, evaluation system, policy oriented and so on. Therefore, the research on the development of sports culture creative industry in Liaoning province has become an urgent problem to be solved. 
This study to the cultural science and economics perspective, the Seventeenth National Congress of the Communist Party of China to determine the scientific development concept as the guiding ideology, to the "cultural province" as the foothold, interaction of sports culture and economic development, expounds the important significance of Liaoning Province to develop sports cultural creative industry, in-depth sports cultural creative industry development advantages, weaknesses, opportunities and threats (SWOT) trend analysis. To promote the brand image, expand the development platform, extend industrial chain and other measures, do a good job in the characteristics of sports culture industry demonstration zone to create work, foster a number of distinctive features, leading industries outstanding sports culture cluster, so as to transform the resource advantage into cultural advantages and economic advantages, promote regional coordinated development and regional economic prosperity, promote the healthy development of sports culture industry in Liaoning province.

\section{Connotation on Sports Culture Creative Industry}

Cultural creative industry is a new industry, which is based on the background of economic globalization. It emphasizes a kind of main cultural or cultural factors that rely on individual (team) through technology, creative and industrial development, marketing intellectual property. Cultural and creative industries mainly include radio, film, animation, audio and video, media, visual arts, performing arts, crafts and design, sculpture, environmental art, advertising, fashion design, software and computer services, such as. Sports cultural creative industry is a cultural and creative industries with high level of cultural connotation and respected creativity and wisdom of man, to highlight the creative, innovative ability is characterized, condensation of the wisdom and creation, to sports cultural creative as a means, to sports and culture as the core, through the technical support and market-oriented operation can is the industrialization of the sum of [3]. Sports cultural creative industry as the sum of the industrial activities, including sports animation, sports exhibition industry, sports publishing, sports advertising, sports tourism, sports entertainment, sports events, sports events, sports events, sports events, such as the content of the industrial activities. Sports culture creative industry sports cultural creative industry is highly innovative, emphasizing the sports culture to the social economy brings new ideas and great driving force. The development of sports culture and creative industry depends on the sports culture and sports culture. The development of sports culture and creative industry depends on the development of sports industry. At the same time, it is possible to develop new growth point of sports industry.

\section{Important Significance on Development for Sports Culture Creative Industry in Liaoning Province}

(1) The development of sports culture and creative industries, promote the realization of the strategic goal of "cultural province" in our province. Under the background of the construction of socialist culture and power, the province of the Eleventh Party Congress proposed the goal of the construction of "cultural province", Liaoning as a big province of culture to the cultural resources and talent advantages, we should adhere to the social benefits in the first place, the unity of social benefit and economic benefit, to promote our province to realize scientific development, innovation and development, harmonious development to provide important support. Liaoning province has the characteristics of sports culture and leisure, sports competitions, sports lottery, sports events, Sports Animation and other sports cultural creative industry characteristics and resources. Therefore, it is of great significance for the development of sports culture and creative industry resources to promote the economic development of Liaoning, improve people's living standards, and accelerate the realization of the goal of building a well-off society in an all-round way. Liaoning provincial government departments to vigorously develop sports cultural creative industry, and strive to build a modern sports industry system, will continue to promote the sports science and technology innovation, improve the level of cultural industry, the realization of "cultural province" of the strategic goal in our province. 
(2) The full implementation of the "State Council on the recent support for the revitalization of the northeast of a number of major policy initiatives," an effective way. To promote the development of the northeast industrial base, the State Council in July 2014 and the introduction of the State Council on the recent support for a number of major policy initiatives to support the revitalization of Northeast China, once again a policy to revitalize the Northeast work carried out a comprehensive plan. "Opinions" to "support the development of strategic emerging industries, the northeast region with the development conditions and the comparative advantage of the field, the national priority layout". On this basis, the paper puts forward the strategy of developing Liaoning province sports culture and creative industry, and explores the development scale and operation mode of sports culture creative industry.

(3) Develop new culture industry, enhance the competitiveness of the cultural industry in Liaoning province. Liaoning Province is the province of the country's sports, sports cultural creative industry is rich in resources: with the natural landscape and rich tourism resources of sports; with leading folk culture festival sports activities many; to based on the historical culture of Manchu sports spread long; in the ten second session of the games for it in the West of Liaoning Province regional characteristics of urban sports culture has gradually formed; community sports culture diversified; leisure industry development rapidly. Therefore, Liaoning Province, by adjusting the structure of the cultural industry, promoting the upgrading of industrial structure, the combination of "characteristic sports cultural resources" and "modern creativity", create a sports culture which can promote the Liaoning sports culture and meet the needs of the consumers. This can promote the survival and development of the sports culture industry in Liaoning Province, is conducive to the cultivation of new cultural formats, and enhance the competitiveness of the cultural industry in Liaoning province.

(4) To achieve the optimization and upgrading of the structure of the culture industry, and promote the formation of new growth point of economic development in our province. Creative industries can create huge economic benefits, not only because it is a new form of industry, but more important is the creative production as a factor has become an important means of promoting economic growth [4]. In the process of industrialization development, there are some problems in Liaoning province sports culture, such as imperfect policies, unreasonable industrial structure, lack of human resources, and the lack of awareness of cultural industry project. Therefore, the Liaoning provincial government departments will be through macro planning and micro implementation, set up a set of sports culture protection, excavation, consolidation of long-term mechanism. Realize the optimization and upgrading of the structure of the culture industry, promote the formation of new growth point of economic development in our province.

(5) The formation of cultural industry group, accelerate the construction of cultural industry base and regional characteristic sports culture industry group. Liaoning Province with geographical advantages, the use of Shenyang, Anshan, Liaoning); Jinzhou, Panjin, Liaoning Province); Dalian, Yingkou (Liaoning South); Dandong, Benxi, Liaoning); Fushun Tieling (northern) etc. the unique features of regional sports culture area, it is clear that the development of road, forming sports cultural creative industry group advantage, development and cultural and sports related sports animation, sports meeting and exhibition industry, sports publishing industry, sports advertisement, sports tourism, sports entertainment, tickets to sporting events and sales, sports event TV copyright in various stereo development mode. The formation of sports culture industry group, accelerate the construction of cultural industry base and regional characteristic sports creative culture industry group.

(6) Enrich the research content of sports culture, develop the research field of regional sports culture creative industry. Domestic scholars have studied the theory of sports culture, such as philosophy, sociology, psychology, management and economics, and so on, the research level is wide, the penetration depth. But the research results are limited in the leisure industry market, behavior and other aspects of the product, and for regional sports cultural creative industry research understood, is still in the pioneering stage. This study advocates the construction of "sports leisure" industry group in Liaoning coastal economic zone, and the region as the category of industrial 
cluster planning, provides a new research ideas for sports culture, and expand the research field of sports culture industry.

\section{SWOT Analysis on Development for Sports Culture Creative Industry in Liaoning Province}

\section{Advantage analysis}

(1) The government attaches great importance to and has promulgated a number of policies to support. The various cities in Liaoning province have also developed their own policies to support the culture industry. This shows that the government in the cultural and creative industries, including sports and cultural industries, and take a number of measures to the rapid development of the cultural and creative industries to pave the way.

(2) The development of sports culture and creative industry in Liaoning province is the foundation of good. The development of sports culture and creative industry can not be separated from the development of economy, the economy is the foundation of its development, and the economic development of Liaoning province is becoming more and more developed [5]. At the same time, Liaoning is a big province of sports, sports culture has a long history, with excellent sports culture tradition and strong cultural heritage.

(3) It has a relatively broad market and strong consumer demand. Liaoning province has a large population, a huge population of the sports and cultural and creative industries of the market and people's consumption needs. With the increasing living standards of the people, the sustainable increase of disposable income of residents, sports consumption will gradually become an important part of people's life consumption, so as to promote the development of sports culture and creative industry [6].

\section{Disadvantage analysis}

(1) The internal structure of the creative industry of sports culture in Liaoning province is unreasonable. The internal structure of the industry makes the creation of creative products, creative enterprises and creative services. The sports service industry in Liaoning province is too low, which directly hinders the development of sports culture and creative industry.

(2) The relative lag behind the development of sports culture and creative industry. As a kind of knowledge intensive industry, sports cultural creative industry has the characteristics of innovation, permeability, high - added value, strong fusion and lasting profit. [7]. Not only do people know about it, relevant government departments to its connotation and characteristics are also not known.

(3) The investment and financing difficulties of the relevant enterprises. Capital difficulty is one of the threats to the small and medium-sized enterprises in sports culture and creative industry. Compared with the development of creative industry system in Liaoning Province, the financing system of cultural and creative industry is slow, which is mainly reflected in the financing, loan, guarantee and so on.

\section{Opportunity analysis}

(1) The Twelfth National Games of chance. In 2013, the second session of the National Games held in 14 cities of Liaoning Province, promote the city sports cultural creative economic development. National industry for the promotion of tourism and for the promotion of the entertainment industry, to promote cultural and sports and other aspects of is obvious. This good opportunity to complement each other, mutual promotion and common development.

(2) Liaoning coastal economic belt development policy. In order to promote the development of coastal economic zone, Liaoning province has issued a number of policies to encourage the development of coastal areas to expand the opening of the coastal areas, the Liaoning coastal economic zone is a national strategy, the national development of a series of support and promote the development of the northeast old industrial base and the development of Liaoning coastal economic belt. Should seize the opportunity to bring this strategy, and vigorously in the coastal cities of Liaoning to develop their own sports culture and creative industries. 


\section{Threat analysis}

(1) Intellectual property protection system is not perfect. Liaoning and the national intellectual property protection of sports culture and creative industries is not in place, the key factors that restrict the development of cultural creative industry, the sports industry management department is not enough.

(2) Lack of high-end talent. The key factor of the development of sports culture and creative industry is the talent. Liaoning province sports cultural creative industry talent is not much, management personnel, high level management and business leaders is extremely scarce.

(3) The ability to compete with foreign countries is weak. Compared with the development of domestic sports culture and creative industry, the development of sports culture and creative industry in Liaoning Province, such as Beijing, Shanghai and Guangzhou, has started relatively late. Compared with the United States and other developed countries, Liaoning Province, sports and cultural and creative industries in the beginning of the late.

\section{Conclusion}

The development of economy needs the character of culture, and the economy can be more healthy and orderly development of [8]. Sports cultural creative industry is a fresh force to promote the development of sports economy, Liaoning province sports culture creative industry is still in the initial stage of development, many factors restrict and influence the development of sports culture creative industry. This paper analyzes the potential and advantages of sports culture creative industry from the perspective of Economics (SWOT), in order to arouse people's attention to sports culture and creative industries, expand the development of sports culture creative industry in Liaoning Province, and realize the cultural advantage and economic advantage, and promote the rapid development of sports culture creative industry in Liaoning province.

\section{Acknowledgement}

This work is supported by social science fund project of Liaoning province (L14BTY002): Development Strategy Research on "cultural strong province" under the perspective of Liaoning sports cultural creative industry.

\section{References}

[1] Central government portal, "National culture development plan for the "five eleven" period," http://www.gov.cn/jrzg/2006-09/13/content_388046.htm, 2015-9-20.

[2] News of the Communist Party of China, "Liaoning provincial Party Committee on the implementation of the party's six plenary session of the seventeen: The opinions of the decision to accelerate the construction of Cultural Province," http://cpc.people.com.cn/GB/64093/64387/16729818.html, 2015-9-20.

[3] W. Zhou, "Research on the development of sports culture creative industry in China," Master's degree of Shenyang Sport University, 2010.

[4] Y. Yu, "Analysis on the development of sports culture creative industry in China," Sichuan Sports Science, vol. 33, no. 1, pp. 7-9, 2014.

[5] Z. B. Liu, "Preliminary study on the development mode of sports creative industry in China," Contemporary sports science and technology, vol. 3, no. 14, pp. 100-101, 2013.

[6] B. Yin, X. Feng, "Research on creative industry of sports culture in Beijing," Journal of Physical Education, vol. 17, no. 6, pp. 21-24, 2010.

[7] Y. L. Zhang, "Analysis on development strategy of China's sports creative industry," Journal of Physical Education, vol. 20, no. 1, pp. 114-117, 2014. 
[8] L. H. Zhou, "On new economic growth point: Creative industry," Southern economy, vol. 30, no. 1, pp. 15-17, 2005. 